\title{
CORPORATE SOCIAL RESPONSIBILITY STANDARDS: IS IT POSSIBLE TO MEET DIVERSE CUSTOMER REQUIREMENTS?
}

\author{
Andrea SÜTÖOVÁ, Ferdinand KÓČA \\ Technical University of Kosice
}

\begin{abstract}
:
The purpose of the study is to review the internationally recognised CSR (Corporate Social Responsibility) standards, codes of conduct (cross-industry and industry-specific used in electronics, automotive and steel industry) and selected codes and supplier evaluation approaches applied by individual customer organisations. It also aims to identify problems related to CSR compliance demonstration from the view of supplier organization supplying its products for more industry sectors. Literature review, interview with the selected large manufacturing organisation and synthesis of information were conducted to achieve the purpose of the study. The difficulties for supplier organisations during CSR verifications and audits conducted by customers or third parties according to a variety of standards are discussed in the paper. It often results from different structure, terminology and content of the CSR standards and codes. One of the possible solutions is to create and maintain the intelligent database of CSR requirements of customer organisations. There is a lack of studies dealing with the existence of various CSR standards and codes and its impact on suppliers supplying their products to more industry sectors. The paper contributes to fill the knowledge gap and extend the existing literature.
\end{abstract}

Key words: audit, customer requirements, codes of conduct, corporate social responsibility, supply chain

\section{INTRODUCTION}

The number of suppliers for raw materials and products a company has access to has been growing rapidly in recent years as a consequence of the increased globalisation. Stakeholders' growing interests and more complex globalised business phenomena and relationships have pushed the development and integration of socially responsible practices within organisations in various global and local industries [1, 2]. Organisations, especially those operating in global markets, are increasingly required to balance the social, economic, and environmental components of their business while building shareholder value. CSR is no longer the individual organisation's domain, increasingly, it encompasses the entire supply chain [3]. Large multinational organisations are expected to hold responsible for environmental and labour practices of their global trading partners such as suppliers, third-party logistics providers, and intermediaries over which they have no ownership [4]. Evidence of abusive or illegal treatment within organisation or its supply chain can damage organisation's brand. Examples of firms are Apple, Zara and Nestle's KitKat, whose supply chains have all been alleged to involve unsustainable practices [5]. Likewise, showing concern for sustainability down the supply chain can raise an organisation image and reputation. Sustainability is regarded as a key ingredient of competitive advantage [6]. Large multinational corporations develop and apply their own codes of conduct, which are mostly supported by sophisticated management systems and, in many cases, develop codes also for their suppliers to show their commitments to CSR aspects and fulfil demands coming from stakeholders. Codes of conduct are often derived from local and international laws, conventions, and standards and are supplemented by organisations ' own CSR strategies and priorities [7]. The supplier code of conduct states clear expectation for suppliers and drive CSR in organisation's supply chain. It prescribes norms and principles, which suppliers have to agree to and comply with if they want to successfully uphold the business relationship with their customers $[8,9]$. In addition, organisation can ask its suppliers for certificates which authenticate the compliance with environmental and social requirements. Such standards, and codes can provide valuable criteria for decision-making within selection and evaluation process as well as performance improvements along the supply chain [10]. The compliance with the codes and standards is evaluated by using various self-assessment and audit approaches $[11,12]$. 
There are several universal and industry specific (e.g. electronics, apparel, extractive, automotive, agriculture, construction, etc.) international standards with monitoring and certification or labelling schemes developed by multistakeholder groups, industry groups and business association, which can be applied in organisations and their supply chain. The benefit of the usage of generic CSR standards by customer organisations is that it alleviates the burden on suppliers to comply with multiple codes of conduct. Sharing codes, auditing systems and compliance procedures to manage suppliers can avoid inefficiency, confusion, and higher costs in implementing, monitoring, and improving remediation of non-compliant CSR activities in supply chains [13]. However, many organisations make modifications and adapt the standards to their values and priorities, define additional CSR requirements or use their own codes along with some other industry code $[9,14]$. Suppliers may be confronted with multiple CSR strategies of their customers incorporating different codes of conduct and requirements, with which they need to comply with.

Several empirical studies have been conducted to investigate how organisations drive CSR and work with CSR-related issues in their supply chains, e.g. $[4,7,11,15,16]$ but only few studies have dealt with the issues how supplier organisations confront business requirements related to CSR, such as certification and compliance requirements, or proof of CSR related business practices $[13,17]$. There is no evidence about the studies dealing with the problems faced by supplier organisations in proving CSR compliance with diverse requirements of customers operating in different industry sectors and applying different codes and standards (including individual codes) within their supply chain. We aim to contribute to fill the knowledge gap and extend the existing literature by addressing the following questions:

- RQ1: Which CSR standards and evaluation approaches are used by customer organisations within their supply chain?

- RQ2: Which problems arise for supplier organisation during the demonstration its compliance with CSR requirements of customers from various sectors?

- RQ3: Which are the possible solutions for supplier organisations to solve the problems related to the demonstration of their CSR compliance?

In our paper, we focus on presentation of the problems occurring during the CSR self-assessments and external audits from the view of supplier organisation, which faces diverse CSR customer requirements from different industry sectors.

To answer the above-mentioned questions, the study first presents the detailed methodology applied by the authors. This section is followed by the review and synthesis of literature and information about universal CSR codes and standards, industry specific and individual CSR standards and codes applied in electronics, automotive and steel industry. This paves the way for the section present- ing the problems regarding CSR compliance demonstration from the view of supplier and possible solution is presented as a subject of further research.

\section{METHODOLOGY}

Literature review and interview with the representatives of the large manufacturing organisation operating in the metallurgy sector were conducted. The work carried out by the authors included steps represented by the Fig. 1.

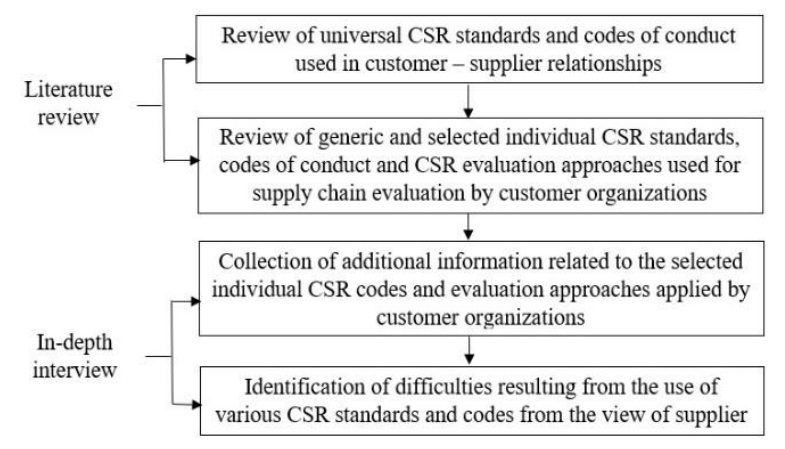

Fig. 1 Flowchart of the methodology

Literature review focused on the existing universal and selected generic (electronics, automotive, and metallurgy sector) CSR standards and codes, which can be used as a basis for the evaluation purposes of organisations` supply chain. It also focused on the selected individual CSR codes, standards and evaluation approaches applied by organisations within their supply chain, while core subjects, requirements and evaluation approaches were summarized.

The interviewed organization supplies its products mainly to electronics, automotive industry and steel processors. The organisation has its own Code of Conduct including the main three CSR areas (social, environmental and economic) and has experience with CSR self-assessments and audits. The interview was conducted with the three ISO management system experts (quality management system manager, environmental management system manager and health and safety manager) of the organization. Two open questions were discussed and answered, the RQ1 and RQ2 while regarding the RQ1 mainly individual CSR standards, requirements and evaluation approaches of customer organizations operating in electronics, automotive and steelmaking industry were discussed. It enabled us to get information beyond those gained from the literature sources and prepare a valuable summarization of information.

\section{RESULTS AND DISCUSSION}

Literature review contributed to answer the RQ1, while the interview helped to complete the information, which were not present in the literature. The first four subchapters are addressed to the RQ1. The interview enabled to answer the RQ2 and the main issues related to the variety of CSR standards and evaluation approaches from the perspective of supplier. Possible solution was proposed which might answer the RQ3. The discussion of the interview results and proposed solution for supplier organization are part of the last two subchapters. 


\section{Review of Universal CSR Standards}

Table 1 shows the selected universal (cross-industry) CSR codes and standards, which may form the basis for defining the scope of information to be reviewed during CSR audits in a supply chain. IQNet SR 10 is a management system standard based on the principles and recommendations of ISO 26000. ISO 26000 provides guidance on CSR and its integration throughout the organisation, but it is not a certifiable standard and it is not usually used for supplier evaluation. However, this standard is a basis for many other standards, methodologies or initiatives worldwide, thanks to a comprehensive overview most of the CSR recommendations. Except the IQnet SR 10, there are also additional certification and verification standards which have been developed in some countries on the base of the ISO 26000, e.g., ČSN 01039 CSR Management System: Requirements (Czech Republic), XP X 30-027: Enhance credibility of an ISO 26000 - based social responsibility approach (France), DS 49001 Social Responsibility Management System: Requirements (Denmark), ONR 192500:2011-11, Social Responsibility of Organisations (Austria), BS 8900 Guidance for Managing Sustainable Development (UK), etc. [18].
IQNet, SA 8000, WCA, SMETA, BSCI and ETI described in the Table 1 are codes and standards according to which CSR audits can be conducted in supplier organisations. The motivation for using the selected standard and evaluation framework in organisations' supply chains can differ from organisation to organisation. SA 8000 and IQNet are management system standards and are compatible with the ISO management system standards, e. g. ISO 9001, ISO 14001, ISO 37001, ISO 45001, which can be also required within CSR audits and assessments [19, 20, 21, 22]. The codes and standards in Table 1 involve all the core CSR areas (social, environmental, business), except ETI and SA 8000 , which focus on the social field.

There are also other CSR tools such as GRI (Global Reporting Initiative), providing standards for reporting of organizations 'sustainability impacts. The CSR reports can be assured by an independent organization, what can reduce information risk and may help supplier organizations to demonstrate their compliance with CSR requirements of customer organizations [30, 31]. However, taking into account a purpose of the study, we selected the most relevant standards presented in the Table 1.

Table 1

Universal CSR Standards

\begin{tabular}{|c|c|}
\hline $\begin{array}{c}\text { CSR Standard Publisher-Country } \\
\text { Release/last version }\end{array}$ & $\begin{array}{c}\text { Purpose } \\
\text { and Brief Description }\end{array}$ \\
\hline $\begin{array}{l}\text { ISO } 26000 \\
\text { Guidance on social responsibility. } \\
\text { ISO - Switzerland; } 2010 / 2010 \text { [23] }\end{array}$ & $\begin{array}{l}\text { Comprehensive guidance on CSR. It is known worldwide and taken as a basis for many } \\
\text { standards. It includes seven core CSR subjects and doesn't serve for certification pur- } \\
\text { poses. }\end{array}$ \\
\hline $\begin{array}{l}\text { IQNet SR10 } \\
\text { Social Responsibility Management Systems } \\
\text { - Requirements } \\
\text { IQNet-Switzerland; 2011/2015 [24] }\end{array}$ & $\begin{array}{l}\text { Management system standard for auditing and certification. It is based on the princi- } \\
\text { ples and recommendations of ISO } 26000 \text {. The standard is compatible with other ISO } \\
\text { management system standards and SA } 8000 \text {. }\end{array}$ \\
\hline $\begin{array}{l}\text { SA8000 } \\
\text { Social Accountability. } \\
\text { Social Accountability International - USA; } \\
\text { 1997/2014 [25] }\end{array}$ & $\begin{array}{l}\text { The auditable and certifiable standard for social compliance to demonstrate a commit- } \\
\text { ment to a human working environment nd represents responsible production. }\end{array}$ \\
\hline $\begin{array}{l}\text { SMETA } 6.1 \\
\text { Sedex Members Ethical Trade Audit } \\
\text { SEDEX - England; 2010/2019 [26] }\end{array}$ & $\begin{array}{l}\text { It is the audit methodology created by the Sedex membership to give centrally agreed au- } \\
\text { dit protocol. It uses the ETI Base Code and the local laws as its monitoring standards. } \\
\text { SMETA 2-Pillar audit comprises of Labour Standards and Health and Safety. 4-Pillar au- } \\
\text { dit comprises of Labour Standards, Health and Safety, Environment and Business Eth- } \\
\text { ics. }\end{array}$ \\
\hline $\begin{array}{l}\text { BSCl } \\
\text { Business Social Compliance Initiative BSCI- } \\
\text { Belgium; 2009/2014 [27] }\end{array}$ & $\begin{array}{l}\mathrm{BSCl} \text {, a program of the Foreign Trade Association. It is designed to improve CSR in a } \\
\text { supply chain of BSCl's participating member companies. It sets Amfori BSCI Code of } \\
\text { Conduct and Implementation System and provides an audit methodology and platform } \\
\text { with supply chain performance information. It is not used for certification purposes. }\end{array}$ \\
\hline $\begin{array}{l}\text { ETI } \\
\text { Ethical Trading Initiative } \\
\text { ETI - UK; 2012/2018 [28] }\end{array}$ & $\begin{array}{l}\text { The ETI Base Code comprising of } 9 \text { elements which reflect the most relevant conven- } \\
\text { tions of the ILO with respect to labour practices. } \\
\text { It is used as a global standard against which social audits are conducted. It is not a cer- } \\
\text { tification scheme. }\end{array}$ \\
\hline $\begin{array}{l}\text { WCA } \\
\text { (Workplace Condition Assessment) } \\
\text { Intertek; } 2014 \text { [29] }\end{array}$ & $\begin{array}{l}\text { WCA is a risk-based assessment tool and audit standard developed by Intertek (testing } \\
\text { and certification service provider). It is aligned with industry standards and best prac- } \\
\text { tices e. g. Global Social Compliance Program (GSCP) and top retailers and brands. }\end{array}$ \\
\hline
\end{tabular}


Except for the mentioned cross-industry codes and standards (applicable for organisation of all types and size), industry-specific codes regulating dealings between industry participants are used. Even codes developed and used by individual organization can regulate customer-supplier relationships. Our study focuses on the codes and evaluation frameworks used in electronics, automotive, and steel making industry and individual codes of organisations operating within these sectors.

\section{Review of CSR Standards and Requirements in Electron- ics}

Many electronics companies (including leaders like LG, Samsung, Siemens, etc.) have adopted the Responsible Business Alliance (RBA) Code of Conduct, which is also a condition for cooperation for their suppliers. RBA is the world's largest industry coalition dedicated to corporate social responsibility in global supply chains. The members are comprised mostly by electronics companies, but it is also applicable for other industry sectors. The third-party audits carried out by RBA member facilities and their suppliers' facilities are according to the RBA Validated Assessment Program (VAP). However, some of the leaders in electronics have their own codes of conduct or standards reflecting the values and priorities of the organisations and suppliers are expected to comply with them. Table 2 presents the core subjects of RBA and two selected organisations' supplier codes. They are not members of the RBA and use their own codes and audit methodologies within their supply chain.

Table 2

CSR Standards and Supplier Evaluation Approaches in Electronic Industry

\begin{tabular}{|c|c|c|}
\hline $\begin{array}{c}\text { CSR } \\
\text { Standard }\end{array}$ & $\begin{array}{l}\text { Core Subjects and Require- } \\
\text { ments }\end{array}$ & Audit Approach \\
\hline $\begin{array}{l}\text { RBA (Re- } \\
\text { sponsible } \\
\text { Business Alli- } \\
\text { ance) [32] }\end{array}$ & $\begin{array}{l}\text { RBA Code of Conduct: } 1 . \text { La- } \\
\text { bour; } 2 . \text { Health and Safety; } \\
\text { 3. Environment; } 4 . \text { Ethics; } 5 . \\
\text { Management Systems }\end{array}$ & $\begin{array}{l}\text { RBA's VAP, au- } \\
\text { ditable by third- } \\
\text { party }\end{array}$ \\
\hline $\begin{array}{l}\text { Electrolux } \\
\text { Supplier } \\
\text { Workplace } \\
\text { Standards } \\
\text { [33] }\end{array}$ & $\begin{array}{l}\text { Child Labour; Forced Labour; } \\
\text { Security Arrangements; Health } \\
\text { and Safety; Non-Discrimination; } \\
\text { Harassment and Abuse; Discipli- } \\
\text { nary Action and Grievances; } \\
\text { Working Hours; Compensation; } \\
\text { Freedom of association; Envi- } \\
\text { ronmental Compliance; Corrup- } \\
\text { tion, and Business Ethics }\end{array}$ & $\begin{array}{l}\text { CSR audit by } \\
\text { second } \\
\text { or third party } \\
\text { against Electro- } \\
\text { lux Supplier } \\
\text { workplace } \\
\text { standard }\end{array}$ \\
\hline $\begin{array}{l}\text { BSH Code } \\
\text { of Conduct } \\
\text { for Supplier } \\
{[34]}\end{array}$ & $\begin{array}{l}\text { Laws and Regulations; Corrup- } \\
\text { tion and Bribery; Human Rights; } \\
\text { Forced Labour; Child Labour; } \\
\text { Harassment; Compensation; } \\
\text { Hours of Work; Non-Discrimina- } \\
\text { tion; Health and Safety; Free- } \\
\text { dom of Association and Collec- } \\
\text { tive Bargaining; Environment; } \\
\text { Supply Chain }\end{array}$ & $\begin{array}{l}\text { CSR audit con- } \\
\text { ducted } \\
\text { by third party } \\
\text { against Code of } \\
\text { Conduct } \\
\text { for Supplier }\end{array}$ \\
\hline
\end{tabular}

Review of CSR Standards and Requirements in Automotive Industry

IATF 16949, which is a certifiable and compulsory standard for organisations within the automotive supply chain, includes in chapter 5.1.1.1 requirements on CSR. The requirements on the field of CSR were added during the last revision of the standard, which was published in 2016. The partnership of leading automotive companies - Drive Sustainability (DS) leading the transformation towards a circular and sustainable automotive value chain promotes the Global Automotive Sustainability Guiding Principles (GASGP), which outline expectations for suppliers on key responsibility issues. Common Self-Assessment Questionnaire (SAQ 3.0) on the base of GASGP was developed, which is used by some automotive companies for sustainability evaluation of their suppliers. In the future, also the common audit standard will be developed by the DS [35]. Core CSR subjects of IATF 16949 and SAQ 3.0 are presented in Table 3.

Automotive companies have sustainable standards or codes of conduct for their suppliers, and compliance with them is a condition for future cooperation. The selected ones are briefly described in Table 4. Some automotive companies have already embedded the GASGP into their existing supplier standards and codes.

Table 3

CSR Standards and Requirements in Automotive

\begin{tabular}{|l|l|}
\hline Standard & Core Subjects and Requirements \\
\hline IATF 16949 & $\begin{array}{l}\text { CSR Policies, including at a minimum an An- } \\
\text { tibribery Policy, Employee Code } \\
\text { of Conduct, Ethics Escalation Policy. }\end{array}$ \\
\hline $\begin{array}{l}\text { GASPG } \\
\text { [36] } 3.0\end{array}$ & $\begin{array}{l}\text { 1. Working Conditions and Human Rights } \\
\text { (Child Labour, Wages and Benefits, Working } \\
\text { Hours, Forced Labour, Freedom of Associa- } \\
\text { tion, Health \& Safety, Harassment, } \\
\text { Non-Discrimination); 2. Business Ethics (Re- } \\
\text { sponsible Sourcing of Materials, } \\
\text { Anti-Corruption, Privacy, Financial Responsi- } \\
\text { bility/Accurate Records, Disclosure } \\
\text { of Information, Fair Competition/Anti-Trust, } \\
\text { Conflicts of Interest, Counterfeit Parts, Intel- } \\
\text { lectual Property, Export Controls and Eco- } \\
\text { nomic Sanctions, Protection of Identity } \\
\text { and Non-Retaliation ); } \\
\text { 3. Environment (Energy Consumption \& } \\
\text { Greenhouse Gas Emissions, Water Quality \& } \\
\text { Consumption, Air Quality, Natural Resources } \\
\text { Management and Waste Reduction, Responsi- } \\
\text { ble Chemical Management) }\end{array}$ \\
\hline
\end{tabular}

Compliance with codes and standards are evaluated by a variety of assessment tools and audit methodologies. Those companies, who are a part of the DS use the SAQ 3.0 for CSR performance evaluation and monitoring of their suppliers. PSA Group uses the services of sustainability rating provider - Eco Vadis. The EcoVadis platform is quickly emerging as a standard for supplier CSR performance monitoring, used in many different industry sectors. Performance is evaluated in four sustainability areas (environment, ethics, labour and human rights, sustaina- 
ble procurement) by scorecards [37]. Supplier performance evaluation in FCA group is conducted by the Supplier Sustainability Self-Assessment method of the Automotive Industry Action Group (AIAG) consisting of five sustainability areas (health and safety, human rights, environment, diversity, compliance, and ethic). In addition to assessments, on-site audits are performed in supplier organisations identified as risky suppliers on the base of criteria such as e.g. country, products and processes.

Table 4 CSR Standards and Supplier Evaluation Approaches Used by Automotive Companies

\begin{tabular}{|c|c|c|}
\hline $\begin{array}{l}\text { Organization`s } \\
\text { CSR standard }\end{array}$ & $\begin{array}{c}\text { Core Subjects } \\
\text { and Requirements }\end{array}$ & $\begin{array}{c}\text { Assessment/Audit } \\
\text { Approach }\end{array}$ \\
\hline $\begin{array}{l}\text { BMW Group } \\
\text { supplier sustaina- } \\
\text { bility policy [38] }\end{array}$ & $\begin{array}{l}\text { 1. Environmental Re- } \\
\text { sponsibility; } 2 \text {. Social } \\
\text { Responsibility; 3. Gov- } \\
\text { ernance; } 4 \text {. Supply } \\
\text { Chain Responsibility } \\
\end{array}$ & $\begin{array}{l}\text { SAQ 3.0/accepted } \\
\text { audit standards - } \\
\text { WCA (Workplace } \\
\text { Condition Assess- } \\
\text { ment), SMETA }\end{array}$ \\
\hline $\begin{array}{l}\text { DAIMLER`s Sup- } \\
\text { plier Sustainability } \\
\text { Standards } \\
\text { [39] }\end{array}$ & $\begin{array}{l}\text { 1. Labour Standards; } \\
\text { 2. Business Ethics } \\
\text { and Compliance; } 3 . \\
\text { Environmental Protec- } \\
\text { tion and Safety } \\
\end{array}$ & $\begin{array}{l}\text { SAQ 3.0/not availa- } \\
\text { ble }\end{array}$ \\
\hline $\begin{array}{l}\text { FORD`s Code of } \\
\text { Human Rights, } \\
\text { Basic Working } \\
\text { Conditions and } \\
\text { Corporate Respon- } \\
\text { sibility [40] }\end{array}$ & \begin{tabular}{|l|} 
1. Human Rights and \\
Working Conditions; \\
2. Community Engage- \\
ment and Indigenous \\
Populations; 3. Brib- \\
ery and Corruption; 4 . \\
Environment and Sus- \\
tainability, 5. Respon- \\
sibility and Implemen- \\
tation
\end{tabular} & $\begin{array}{l}\text { SAQ 3.0/RBA's VAP } \\
\text { (third-party audit) } \\
\\
\\
\end{array}$ \\
\hline $\begin{array}{l}\text { PSA Group Re- } \\
\text { sponsible Pur- } \\
\text { chase Policy } \\
{[41,42]}\end{array}$ & $\begin{array}{l}\text { 1. Social principles; } 2 . \\
\text { Environmental protec- } \\
\text { tion; } 3 . \text { Ethical princi- } \\
\text { ples; } 4 \text {. Sustainable } \\
\text { procurement }\end{array}$ & $\begin{array}{l}\text { Ecovadis Plat- } \\
\text { form/PSA } \\
\text { Group own meth- } \\
\text { odology } \\
\text { (third-party audit) } \\
\end{array}$ \\
\hline $\begin{array}{l}\text { Volkswagen Group } \\
\text { Code of Conduct } \\
\text { for Business Part- } \\
\text { ners [43] }\end{array}$ & $\begin{array}{l}\text { 1. Environmental Pro- } \\
\text { tection; } 2 \text {. Human } \\
\text { Rights and Labour } \\
\text { Rights of Employees; } \\
\text { 3. Transparent Busi- } \\
\text { ness Relations; 4. Fair } \\
\text { Market Behaviour; } \\
\text { 5. Duty of Care to Pro- } \\
\text { mote Responsible } \\
\text { Raw Material Supply } \\
\text { Chains; } 6 \text {. Integration } \\
\text { of Sustainability Re- } \\
\text { quirements in Organi- } \\
\text { sation and Processes } \\
\end{array}$ & $\begin{array}{l}\text { SAQ 3.0/WCA } \\
\text { (third-party audit), } \\
\text { VW CSR audit } \\
\text { (less detailed than } \\
\text { WCA) }\end{array}$ \\
\hline $\begin{array}{l}\text { FCA Group Sus- } \\
\text { tainability Guide- } \\
\text { lines for Suppliers } \\
{[44]}\end{array}$ & $\begin{array}{l}\text { 1. Human Rights and } \\
\text { Working Conditions; } \\
\text { 2. Environment; } 3 . \\
\text { Business Ethics and } \\
\text { Corruption; } 4 \text {. Moni- } \\
\text { toring and Remedial } \\
\text { Actions }\end{array}$ & $\begin{array}{l}\text { AIAG Supplier Sus- } \\
\text { tainability Self-As- } \\
\text { sessment/ audit as } \\
\text { a part FCA Supplier } \\
\text { Eligibility Assess- } \\
\text { ment (second-party } \\
\text { audit) }\end{array}$ \\
\hline
\end{tabular}

Currently the automotive companies use different sustainability audit methodologies like RBA VAP, WCA, and some of them apply their own individual methodologies as it can be seen in the Table 4. In addition, different audit techniques from examination of records to employee interviews can vary from organisation to organisation.

The above-mentioned supplier sustainability codes and standards mostly overlaps in main sustainability areas. Still, some differences resulting from individual values and priorities of the companies can be found. Using a common approach by some automotive companies for sustainability assessment - SAQ and common platform enables suppliers to voluntarily share their results and eliminates the burden associated with multiple assessments according to different frameworks. However, there are differences in audit methodologies. The common audit methodology has not been developed so far. Some automotive companies accept more audit frameworks.

\section{Review of CSR Standards and Requirements in Steel In- dustry \\ Organisations from every stage of the steel supply chain} developed an independent certification standard and programme ResponsibleSteel, which was first published at the end of 2019. It contains 12 environmental, social, and governance principles. AcelorMittal has been a driving force in the creation of ResponsibleSteel also with other steelmakers such as Voestapine, Blue Scope, and Aperam and OEMs such as Daimler and BMW and civil society organisations. In Table 5 are presented the main principles and requirements of the ResponsibleSteel standard and the example of CSR requirements of steel-producing organisation, which is not a member (Thyssenkrupp) and it has its own code of conduct and uses the WCA methodology for auditing its suppliers.

Table 5 CSR Standards in Steel-Making Industry

\begin{tabular}{|c|c|c|}
\hline $\begin{array}{c}\text { CSR } \\
\text { Standard }\end{array}$ & $\begin{array}{c}\text { Core Subjects } \\
\text { and Requirements }\end{array}$ & $\begin{array}{c}\text { Audit } \\
\text { Approach }\end{array}$ \\
\hline $\begin{array}{l}\text { ResponsibleS- } \\
\text { teel } \\
{[45]}\end{array}$ & $\begin{array}{l}\text { 1. Corporate Leadership; } 2 . \\
\text { Social, Environmental and } \\
\text { Governance Management } \\
\text { Systems; 3. Occupational } \\
\text { Health and Safety; 4. Labour } \\
\text { Rights; 5. Human Rights; } 6 . \\
\text { Stakeholder Engagement and } \\
\text { Communication; 7. Local Com- } \\
\text { munities; } \\
\text { 9. Climate Change and Green- } \\
\text { house Gas Emissions; } 10 . \\
\text { Noise, Emissions, Effluents } \\
\text { and Waste; 11. Water Stew- } \\
\text { ardship; Biodiversity; 12. De- } \\
\text { commissioning and closure }\end{array}$ & $\begin{array}{l}\text { Audit according } \\
\text { to Responsible } \\
\text { Steel Standard } \\
\text { by third-party. }\end{array}$ \\
\hline $\begin{array}{l}\text { Thyssenkrupp } \\
\text { Supplier Code } \\
\text { of Conduct [46] }\end{array}$ & $\begin{array}{l}\text { Human and Labour Rights; Oc- } \\
\text { cupational Health and Safety; } \\
\text { Environmental Protection; } \\
\text { Conduct in Business Environ- } \\
\text { ment; Supplier Relations; } \\
\text { Compliance with the } \\
\text { Thyssenkrupp Code of Con- } \\
\text { duct }\end{array}$ & $\begin{array}{l}\text { Thyssenkrupp } \\
\text { SAQ/ } \\
\text { WCA con- } \\
\text { ducted by third } \\
\text { party }\end{array}$ \\
\hline
\end{tabular}




\section{Discussion of problems arising from different standards and diverse customer requirements that face supplier organizations}

Organisations supplying products for customers from different industry sectors face challenges associated with varying CSR strategies and evaluation frameworks. Except for the existence of universal codes and standards, there are industry-specific codes and related evaluation approaches (assessment or audit methodologies). The extent to which the codes cover the individual CSR subjects can differ between industries. In addition, some organisations have their own codes of conduct and own procedures for CSR verification and monitoring of their suppliers and require individual assessments and audits. This fact brings difficulties for supplier organisation in demonstrating its compliance with a variety of CSR requirements of their customers during assessments and audits conducted by second or third-party. They arise from different terminology, structure and extent of requirements on individual CSR areas included in codes and standards. Many of the requirements related to particular CSR areas overlap (duplication in audit happen), but some of them are specifically connected to a certain industry sector or individual customer's CSR strategy. Supplier undergoes assessments and audits realized according to a variety of methodologies and individual areas are assessed in different depth and extent. Some customer organisations accept other CSR standards, but there are organisations requiring their suppliers to undergo assessments and audits according to their individual procedures. The audit techniques vary from the examination of records to employee interviews with different depth. Suppliers spend time planning, questionnaires processing, preparation of records and auditing itself, which is conducted by customer organisation or third-party. Assessments and audits are associated with costs, which must be covered by the parties involved. Implementation of various standards may make the system complex and bureaucratic.

\section{Discussion of possible solution using intelligent technol- ogies}

Intelligent technologies are changing our lives and business. The use of intelligent technologies in the field of CSR and sustainable development is gaining in importance. Several papers have focused on the use of intelligent technologies in CSR management and pointed out their benefits, e. g. the use of blockchain in supply chain management $[47,48]$ and use of artificial intelligence and cognitive technologies for decision making on CSR future direction and development $[49,50]$. Artificial intelligence (AI) solutions can help to optimize the CSR programs of organizations and improve their CSR performance. Cognitive technologies are tool of Al based on computer models that integrate knowledge. Their task is to implement specific patterns of cognitive functions enabling testing of these functions on a wide range of issues. Cognitive technologies enable to obtain the planned economic and organizational effect [51].
In order to solve the problems generated by our study, which relate to CSR audits and self-assessments according to variety of standards and requirements that supplier organization face, the creation and maintenance of intelligent database of CSR customer requirements will be the subject of the future research. The proposed solution might answer the RQ3. Traditional databases no longer provide users with the help they need. Users need various types of information in a short time, and in the required structure, searching through keywords and phrases using Boolean operations such as and, or and not, is no longer enough. An intelligent database is a full-text database with Al components that interact with users to ensure that users are supplied with all relevant information. The Al portion is most often seen during searches providing intellectual operations and knowledge representations that are usually based on the connectionist neural network models. So, an intelligent database is a system that manages information rather than simple data and presents it in such a way that it is natural and informative for users. As a result, its capacity is far beyond simple record keeping $[52,53]$. The proposed solution of intelligent database may help to supplier organizations save time searching for the right documents, data and evidence to demonstrate the compliance with the variety of CSR standards and codes, which can differ in terminology, structure and content.

\section{CONCLUSION}

The paper contributes to the current state of knowledge related to challenges and problems associated with CSR verifications and audits from the perspective of supplier organisations, which results from different standards and requirements of customers. It provides an integrated and synthesized overview of current universal CSR codes and standards, generic CSR standards used in electronics, automotive and steel-making industry as well as selected individual CSR standards and evaluation frameworks used by organisations operating in these industry sectors.

The using of industry specific standards with common monitoring and certification or labelling scheme helps to eliminate burden on suppliers supplying products to a certain sector to comply with multiple individual customers' codes and undergo multiple audits and assessments. However, despite the existence of these generic codes and standards many leading organisations apply their own CSR strategies and evaluation approaches within their supply chain. Organisations supplying products to several industry sectors face challenges to comply with different industry codes and standards and in the case of customer demand with individual customer codes of conduct. The extent to which the codes and standards cover the individual CSR subjects can differ between industries, but some requirements can overlap. Conducting assessments and audits according to different standards is time consuming and it is associated with costs, which must be covered by supplier or customer organisations. Suppliers face difficulties during the demonstration of compliance with multiple codes and standards. It can arise from different 
terminology, structure, and extent to which the standards cover individual CSR areas. The CSR requirements can overlap to varying degrees. One of the possible solutions is to create and maintain the intelligent database of CSR requirements of customers to shorten the time spend by preparing for assessments and audits, which will be the subject of the future research.

\section{ACKNOWLEDGEMENTS}

This work was supported by the Ministry of Education, Science, Research and Sport of the Slovak Republic, project "Improving material engineering and integrated management systems study programs for Industry 4.0", no. 043TUKE-4/2019.

\section{REFERENCES}

[1] W. L. Cheng and J. Ahmad. "Incorporating stakeholder approach in corporate social responsibility (CSR): A case study at multinational corporations (MNCs) in Penang". Social Responsibility Journal, vol. 6 no. 4, pp. 593-610, 2010.

[2] F. Mosca and C. Civera. "The Evolution of CSR: An Intergrated Approach". Emerging Issues in Management, vol. 17 no. 1, pp. 16-35, 2017.

[3] P.C. Chiesa and W. Przychodzen. "Social sustainability in supply chain: a review", Social Responsibility Journal. vol. 16 no. 8, pp. 1125-1148, 2019.

[4] M. Andersen and T. Skjoett-Larsen. "Corporate social responsibility in global supply chains". Supply Chain Management, vol. 14, no. 2, pp. 75-86, 2009.

[5] H. Hofmann, C. Busse, C. Bode and M. Henke. "Sustainability-Related Supply Chain Risks: Conceptualization and Management". Bussines, Strategy and Environment, vol. 23 no. 3, pp. 160-172, 2013.

[6] M. Zhang, Y. K. Tse, B. Doherty, S, Li and P. Akhtar. "Sustainable supply chain management: Confirmation of a higher-order model". Resources, Conservation and Recycling, vol. 128 no. 1, pp. 206-221, 2018.

[7] R. Medina-Serrano, M. Ramirez, J. Gasco. and J. L. Taverner. "Sustainable Supplier Evaluation practices across the Supply Chain". Direccion y Organizacion. vol. 69, pp. 13-26, 2019.

[8] S. Colwell, M. Zyphur, and M. Schminke. "When does ethical code enforcement matter in the interorganizational context? The moderating role of switching costs". Journal of Business Ethics, vol. 104 no. 1, pp. 47-58, 2011.

[9] UNCTAD. Corporate Social Responsibility in Global Value Chain: Evaluation and monitoring challenges for small and medium sized suppliers in developing countries. UN: Geneva 2012.

[10] D. Harms, E. Hansen and S. Schaltegger. "Strategies in Sustainable Supply Chain Management: An Empirical Investigation of Large German Companies". Corporate Social Responsibility and Environmental Management, vol. 20 no. 4, pp. 205-218, 2012.

[11] D. E. Boyd, R. E. Spekman, J. W. Kamauff, and P. Werhane. "Corporate social responsibility in global supply chains: A procedural justice perspective". Long Range Planning, vol. 40 no 3, pp. 341-356, 2007.

[12] E. Delbufalo and M. Bastl. "Multi-principal collaboration and supplier's compliance with codes-of-conduct". The International Journal of Logistics Management, vol. 29 no. 4, pp. 1237-1254, 2018.
[13] M. Risso. "A horizontal approach to implementing corporate social responsibility in international supply chains". International Journal of Technology Management, vol. 58 no. 1/2, pp. 64-81, 2012.

[14] M. Asif, M. S. Jajja and C. Searcy. "Social compliance standards: Re-evaluating the buyer and supplier perspectives". Journal of Cleaner Production, vol. 227, pp. 457-471, 2019.

[15] M. Formentini and P. Taticchi. "Corporate sustainability approaches and governance mechanisms in sustainable supply chain management". Journal of Cleaner Production, vol. 112 no 3, pp. 1920-1933, 2016.

[16] E.R. Pedersen and M. Andersen. "Safeguarding corporate social responsibility (CSR) in global supply chains: How codes of conduct are managed in buyer-supplier relationships". Journal of Public Affairs, vol. 6 no. 3-4, pp. 228-240, 2006.

[17] F. Ciliberti, D. Baden, and I. A. Harwood, "Insights into Corporate Social Responsibility Practices in Supply Chains: A Multiple Case Study of SMEs in the UK". Operations and Supply Chain Management: An International Journal, vol. 2 no. 3, pp. 154-166, 2009.

[18] ISO. "Certification, verification, assessment". Internet: https://iso26000.info /certification/ [June 22, 2020].

[19] A. Nagyova, M. Balazikova, and S. Markulik. "Implementation Proposal of OH\&S Management System According to the Standard ISO/DIS 45001", in: Advances in Safety Management and Human Factors, AHFE 2017. P. Arezes, Ed. Sringer, pp. 472-485, 2017.

[20] . Nenadál. "The New EFQM Model: What Is Really New And Could Be Considered As A Suitable Tool With Respect To Quality 4.0 Concept". Quality, Innovation, Prosperity, vol. 14 no. 1, pp. 17-28, 2020.

[21] I. Slimák and K. Zgodavová. "Focus on Success". Quality Innovation Prosperity, vol. 15 no. 1, pp. 1-4, 2011.

[22] K. Teplická, S. Hurná. and D. Spirková. "Evaluation of Environment Efficiency". Quality - Access to Success, vol. 21 no. 177, pp. $104-107,2020$.

[23] ISO. ISO 26000 Guidance on Social Responsibility. ISO, Geneva, 2010.

[24] IQ Net. IQ Net SR10 Social Responsibility Management Systems Requirements. IQ Net: Bern, 2015.

[25] SAI. SA8000 Social Accountability. SAI: New York, 2014.

[26] Smeta. "Smeta Guidance". Internet: www.sedex.com/ourservices/smeta-audit/smeta-documents/ [May 14, 2020].

[27] Amorfi (2019). "Amorfi BSCl". Internet: www.amfori.org/content/amfori-bsci [May 15, 2020].

[28] ETI. "ETI Base Code". Internet: www.ethicaltrade.org/etibase-code [May 15, 2020].

[29] Intertek. "Workplace Condition Assessment". Internet: www.intertek.com/assurance/wca/ [June 20, 2020].

[30] H. Kohl. Standards for Management Systems. Springer: Switzerland, 2020.

[31] M.D. Odriozola and E. Baraibar-Diez: "Is Corporate Reputation Associated with Quality of CSR Reporting? Evidence from Spain". Corporate Social Responsibility and Environmental Management. Vol. 88 no. 15, pp. 121-132, 2017.

[32] RBA. "RBA Validated Assessment Program". Internet: www.responsiblebusiness.org/ code-of-conduct/ [June 22, 2020].

[33] Electrolux. "Sustainability Report 2019". Internet: www.electroluxgroup.com/en [June 22, 2020]. 
[34] BSH. "Global Supply Chain". Internet: www.bshgroup.com/company/global-supply-chain [May 18, 2020].

[35] IATF. IATF 16949:2016 Automotive Quality Management System Standard: Quality management system requirements for automotive production and relevant service parts organizations. Southfield: AIAG. 2016.

[36] Drive Sustainability. "SAQ 3.0 available for Automotive Sector Suppliers". Internet: www.drivesustainability.org/saq-3-0/ [May 15, 2020].

[37] EcoVadis. "Sustainability Assessment". Internet: https://ecovadis.com/suppliers/ [June 15, 2020].

[38] BMW. "Supply Chain Management". Internet: www.bmwgroup.com/en/responsibility /supply-chainmanagement.html [May 15, 2020].

[39] Daimler. "Supplier Sustainability Standards". Internet: https://supplier-portal.daimler.com/docs/DOC-1458 [June 10, 2020].

[40] Ford. "Sustainability Strategy". Internet: https://corporate.ford.com/microsites/ sustainabilityreport-2020/sustainability-strategy.html [May 15, 2020].

[41] PSA Group. "A Responsible Purchasing Policy". Internet: www.groupe-psa.com/en/responsible-purchasing-policy/ [May 10, 2020].

[42] PSA Group. "The B2B Portal". Internet: http://b2b.psapeugeot-citroen.com/pages/en-US/info.aspx [May 10, 2020].

[43] Volkswagen Group. "Compliance". Internet: www.volkswagenag.com/en/group/complianceandriskmanagement/compliance.html\# [May 15, 2020].

[44] FCA. "Sustainability". Internet: www.fcagroup.com/enUS/sustainability/Pages/guidelines.aspx [May 14, 2020].

[45] Responsible Steel. "Certification Resources". Internet: www.responsiblesteel.org/ certification/certificationresources/ [June 22, 2020].

\footnotetext{
Andrea Sütőová

ORCID ID: 0000-0002-6689-046X

Technical University of Kosice

Institute of Materials and Quality Engineering

Department of Integrated Management Systems

Letná 1/9, 04001 Košice, Slovak Republic

e-mail: andrea.sutoova@tuke.sk

\section{Ferdinand Kóča}

ORCID ID: 0000-0002-7528-3506

Technical University of Kosice

Institute of Materials and Quality Engineering

Department of Integrated Management Systems

Letná 1/9, 04001 Košice, Slovak Republic

e-mail: ferdinand.koca@student.tuke.sk
}

[46] Thyssenkrupp. "Responsible Procurement". Internet: www.thyssenkrupp.com/en/ company/procurement/responsible-procurement [June 15, 2020].

[47] M. Giacalone, V. Santarcangelo, V. Donvito, O. Schiavone and E. Massa. "Big data for corporate social responsibility: blockchain use in Gioia del Colle DOP." Quality and Quantity, 2021.

[48] V.G. Venkatesh, K. Kang, B. Wang, R.Y. Zhong, A. Zhang. "System architecture for blockchain based transparency of supply chain social sustainability". Robotics and ComputerIntegrated Manufacturing, vol 63, 2020.

[49] A. Kuzior, A. Kwilinski, V. Tkachenko. "Sustainable Development of Organizations Based on the Combinatorial Model of Artificial Intelligence". Enterpreneurship and Sustainability Issues, vol. 7 no. 2, pp. 1354-1376, 2019.

[50] E. Napier. Technology Enabled Social Responsibility Projects and an Empirical Test of CSR's Impact on Firm Performance. Georgia State University: Atlanta, 2019.

[51] A. Kwilinski and A. Kuzior. "Cognitive Technologies in the Management and Formation of Directions of the Priority Development of Industrial Enterprises". Management Systems in Production Engineering, vol. 28 no. 2, pp. 133138, 2020.

[52] E. Bertino, B. Catania and G. P. Zarri. Intelligent Database Systems, Addison-Wesley Longman Publishing Co.: Boston, 2001.

[53] K. Zgodavova and I. Slimak. "Advanced Improvement of Quality". Annals of DAAAM \& Proceedings, vol. 19 no. 1, pp. 1551-1553, 2008. 